\title{
Confounding in the hyponatremia, bone mineral density and falls relationship
}

\author{
MARINA RUXANDRA OTELEA
}

Clinical Department 2, University of Medicine and Pharmacy, Bucharest

\section{Dear Editor,}

The article "Hyponatremia, bone mineral density and falls in the elderly; Results from AHAP study", by Hosseini et al. [1] raises interesting discussions about the factors that influence the relation between hyponatremia and bone mineralization. In this letter I will briefly summarize the potential confounding factors related to the natremia measurement and to the case and controls selection that might explain a certain disagreement with other epidemiological studies.

Natremia was measured in this study by the photoelectric flame technique. This technique gives accurate results except for the patients with hypertriglyceridemia and hyper- or hypoproteinemia. I agree with the fact that, even if the incidence increases by age, severe hypertriglyceridemia and multiple myeloma are relatively rare disorders in general population and will probably have no statistical influence. On the contrary, hypoalbuminemia is very frequent in elderly people [2]. Hypoalbuminemia gives false hypernatremia or false normonatremia [3] and might have a more significant impact on the results. The low protein level is also associated with decreased bone mass [4] and by itself will influence the analysis. Therefore, inclusion of albuminemia in the analysis will be of a peculiar interest.

Secondly, there are significant differences between the hyponatremic and the normonatremic groups that have to be considered in the interpretation.

The prevalence of hypertension was higher in the normonatremic group. According to a recent metaanalysis, hypertension is directly related to bone density [5]; in support to the epidemiological arguments, several mechanisms (increased calciuria, PTH stimulation of secretion and an elevated osteocalcin secretion) [6] were described. Checking if hypertension is not a confounder of the results would bring a distinct perspective on the relation between hyponatremia and bone density.
Hypertension medication seems also to be an influencer of bone metabolism. The thiazide treatment, the most frequent cause of drug induced hyponatremia in hypertensive patients, was an exclusion criterion; however, the majority $(60.28 \%)$ of the patients included in the study were hypertensive and it is highly improbable that these hypertensive patients should be on ANY treatment that influences bone metabolism. In fact, all first line high blood pressure drugs interfere to calcium or sodium homeostasis: increased bone demineralization was assumed for calcium channels inhibitors [7], while angiotensin converting enzyme or angiotensin receptor blockers inhibitors might be protective [8]. Differences between the case and control groups in the type and amount of these drugs could also bias the results.

BUN is in the upper normal level in cases, significantly higher than in controls and could mark various characteristics of the two populations. Of particular interest to this analysis are the protein intake, which is negatively associated with osteoporosis, and the hydration status, that will affect the natrium concentration. It is of course a matter of speculation that if higher protein intake (reflected in the higher BUN in cases) and hypoalbuminemia (in the control group) match to the diet habits, protein intake would become the most probable confounder of the study results.

The statistically significant lower $\mathbf{K}$ level in cases needs also some considerations, as serum $\mathrm{K}$ is in close relation with diet and with the acid-base balance. Low intake of $\mathrm{K}$ is part of western/unhealthy diet and could be the cause for the significant difference of the $\mathrm{K}$ level. Unhealthy diet is also associated with other factors (higher acid overload, low vitamin $\mathrm{D}$, etc.) that contribute to the bone demineralization in the elderly [9].

Hypopotassaemia is frequently encountered in mild chronic alkalosis or in compensated chronic respiratory acidosis, because bicarbonate excretion implies obligatory $\mathrm{K}$ (and $\mathrm{Na}$ ) urinary loss. Lower $\mathrm{K}$ values are also present in chronic metabolic 
acidosis, due to the diminished exchange of $\mathrm{Na}-\mathrm{H}$ in the proximal tubule and the increased distal $\mathrm{Na}$ delivery, favoring a high $\mathrm{Na} / \mathrm{K}$ exchange. Even if thiazide has been excluded, loop diuretics (mild alkalosis) and acetazolamide (mild acidosis) also impact the acid-base homeostasis and $\mathrm{K}$ excretion. If hypopotassaemia is linked to an impaired acid base equilibrium, this will directly influence bone metabolism: bone acid milieu has demineralization properties, while alkaline $\mathrm{pH}$ is protective [10], stimulating bone marrow stromal cells differentiation
[11]. In bone interstitial tissue, $\mathrm{K}$ is considered the first line of buffering acidosis; therefore a low $\mathrm{K}$ level will have a negative impact on mineralization [10].

In conclusion, the comprehensive presentation of the characteristics of the cases and control groups is a contribution in itself to the quality of the research on this topic. With possible confounders ruled out, the results will bring more added value to the understanding of the complex relation between hyponatremia and bone mass loss.

Correspondence to: Marina Ruxandra Otelea, M.D,Ph D. Clinical Department 2,

University of Medicine and Pharmacy, Bucharest, Romania

E-mail: marina.otelea@umfcd.ro

\section{REFERENCES}

1. HOSSEINI SR, BAGHITABAR N, MIRZAPOUR A, OLIAEI F, NOOREDDINI H, BIJANI A, MOUODI S. Hyponatremia, bone mineral density and falls in the elderly; Results from AHAP study. Rom J Intern Med. 2018;56(1):41-46.

2. BROCK F., BETTINELLI L.A., DOBNER T., STOBBE J.C., POMATTI G., TELLES C.T. Prevalence of hypoalbuminemia and nutritional issues in hospitalized elders. Rev Lat Am Enfermagem. 2016;24:e2736.

3. DIMESKI G., MORGAN T.J., PRESNEILL J.J., VENKATESH B. Disagreement between ion selective electrode direct and indirect sodium measurements: Estimation of the problem in a tertiary referral hospital. J Crit Care. 2012;27: 326.e9-326.e16.

4. AFSHINNIA F., WONG K.K., SUNDARAM B., ACKERMANN R.J., PENNATHUR S. Hypoalbuminemia and osteoporosis: reappraisal of a controversy. J Clin Endocrinol Metab. 2016;101(1):167-175.

5. YE Z., LU H., LIU P. Association between essential hypertension and bone mineral density: a systematic review and metaanalysis. Oncotarget. 2017;8:68916-68927.

6. PÉREZ-CASTRILLÓN J.L., JUSTO I., SILVA J., SANZ A., IGEA R., ESCUDERO P., et al. Bone mass and bone modelling markers in hypertensive postmenopausal women. J Hum Hypertension 2003;17;107-110.

7. AĞAÇAYAK K.S., GÜVEN S., KOPARAL M., GÜNEŞ N., ATALAY Y., ATILGAN S. Long-term effects of antihypertensive medications on bone mineral density in men older than 55 years. Clin Interv Aging. 2014;9:509-513. doi:10.2147/CIA.S60669.

8. KWOK T., LEUNG J., BARRETT-CONNOR E., FOR THE OSTEOPOROTIC FRACTURES IN MEN (MROS) RESEARCH GROUP. ARB users exhibit a lower fracture incidence than ACE inhibitor users among older hypertensive men. Age Ageing, 2017; 46:57-64.

9. DENOVA-GUTIÉRREZ E., MÉNDEZ-SÁNCHEZ L., MUÑOZ-AGUIRRE P., TUCKER KL., CLARK P. Dietary patterns, bone mineral density, and risk of fractures: A systematic review and meta-analysis. Nutrients. 2018;10:1992.

10. KRIEGER N.S., FRICK K.K., BUSHINSKY D.A. Mechanism of acid-induced bone resorption. Curr Opin Nephrol Hypertens. 2004; 13:423-36.

11. LIU W., WANG T., YANG C., DARVELL B.W, WU J., LIN K., et al. Alkaline biodegradable implants for osteoporotic bone defects-importance of microenvironment $p H$. Osteoporos Int. 2015; 27:93-104.

Received February 13, 2019 